DOI 10.38129/ Ann.Yur.Ist.2019.3.3.4.40

УДК 342.571: 342.384.052:(130.2:321.011)

\title{
ГОСУДАРСТВЕННАЯ ИДЕЯ В БЕЛАРУСИ: ПРОБЛЕМЫ СТАНОВЛЕНИЯ В НАЧАЛЕ ХХ ВЕКА
}

\author{
АЛЕКСАНДР КУКСА (Минск, Республика Беларусь)*
}

Весь XIX век на территории Беларуси и Украины шла жесткая идеологическая и вооруженная борьба между сторонниками российской и польской государственности. С целью отвлечения локальной интеллигенции от идеи возрождения польской государственности, власти Российской империи проводят ряд мероприятий по собиранию, изучению и популяризации истории белорусского и украинского народов, пытаясь найти их «общие древнерусские корни». Постепенно местная интеллигенция погружается в изучение собственной истории. Дополнительный виток этому процессу придает «разбор шляхты». Но результат стал неожиданным для России. В Беларуси интеллигенция начинает разрабатывать собственную национальную концепцию, основываясь на идеологеме возрождения Великого княжества Литовского. В свою очередь, в Украине национальное возрождение проходит через виток идеализации Киевской Руси и Запорожской Сечи.

И в первом (белорусском), и во втором (украинском) случаях национальное строительство рассматривалось как самостоятельный процесс, в котором ни Россия, ни Польша уже не выступали покровителями, а исключительно агрессорами, поработителями и врагами национальных интересов белорусов и украинцев. Большое влияние на выработку таких постулатов сыграли национальные революции начала XIX века, прокатившиеся по европейским странам. Именно в 1830-1840-х гг. начали остро дискутироваться интеллектуалами и, соответственно, подниматься в широкой общественной среде вопросы о том, что национальные интересы может защитить только национальное правительство.

Разнообразие возможных геополитических комбинаций на территории Беларуси и Украины продемонстрировали события начала XX века. Вхождение в состав Российской империи предопределило реализацию социально-революционной модели государственности. Пережив события мировой войны и трех российских революций, население белорусских и 
украинских территорий впитало в себя дух силового решения проблемы, стремление к кардинальным изломам. Устав от постоянных потрясений люди видели выход только в уничтожении старого. Существовавшая же политическая система абсолютной монархии не сумела адаптироваться к новым условиям и предоставить альтернативное решение назревшей социально-психологической проблемы.

Традиционное соседство с Россией накладывало отпечаток и на государственно-политическое мышление региональных элит. И в Польше, и в Украине, и в Беларуси, и в странах Балтии первоначально доминировали идеи развития народов, населяющих эти территории, при поддержке официального Петербурга - в пределах российского правового поля (в условиях ограниченной монархии), базируясь на конструкциях разных юридических проектов (персональная автономия, национальнотерриториальная автономия). Однако отсутствие реальных подвижек в политическом мышлении правящей элиты Российской империи и активное влияние на психологию региональных элит европейских мировоззренческих систем (в частности, философско-правовых) актуализировало в перечисленных странах идеи построения национальнодемократической модели государства. Европейские примеры казались привлекательными представителям национальных интеллигенций, но оказались далекими от реальных потребностей местного населения. Отсутствие демократических традиций, налаженных механизмов решения жизненных вопросов (от транспорта, жилья и пропитания, до управления страной), являлось слабой стороной тех партий и общественных организаций, которые в борьбе за власть использовали лозунги национально-демократической модели. Надежда на помощь извне и отсутствие поддержки в народе привели к их поражению в ходе противостояния с более традиционными лозунгами представителей революционных партий. Тем не менее, поражение национальнодемократической модели сменилось пониманием того, что имперская система отжила свой век и новое объединение на обломках Российской империи должно быть образовано на фундаменте национальных государств. Представители советской модели оказались более гибкими политиками и, подхватив эту идею, В. И. Ленин настоял на создании СССР. Советский Союз должен был поглотить все конфликты, возникшие из-за национальных, социальных и религиозных противоречий.

Результатом активного взаимодействия представителей «негосударственных народов» стало провозглашение в 1916 г. приоритета идеи государственной независимости на международных конференциях в 
Стокгольме и Лозанне. В это же время лидеры украинского (М. С. Грушевский) и белорусского (А. И. Луцкевич) национальных движений выделили общую политическую цель, которая рассматривалась ими в форме «Соединенных штатов от Балтийского до Черного морей».

Возможность альтернативного политического развития Беларуси и Украины долгое время отвергалось политическими кругами императорской России. Отношение либеральных российских кругов к национальному движению «на окраинах» охарактеризовал П. Б. Струве. «Программа русских либералов призывала партии, независимо от их политической ориентации, защитить общерусскую культуру в западных регионах страны и определить свое отношение к белорусскому и украинскому национальному возрождению. Смысл этого призыва сводился к тому, чтобы ограничить развитие белорусской и украинской культуры в рамках местных особенностей быта и традиций. И, естественно, ставилась задача не допустить в Белоруссии и на Украине реализации национальногосударственной идеи». И далее предупреждал, что если она «ударит в народную основу и зажжет ее, то это будет неслыханным и величайшим расколом российской нации и станет подлинным государственным и народным бедствием» ${ }^{1}$. Поэтому П. Б. Струве предлагал ограничить национальное движение рамками скромного областного развития.

В Польше национальный вопрос стоял особо остро. Стремление к национальной независимости проявлялось во всех политических и общественных организациях. Дискуссия возникала только вокруг границы, в рамках которой должен был осуществляться государственный суверенитет: в пределах всех трех частей, разделенных между Россией, Германией и Австрией (Домбский) или только Царства Польского (Пилсудский), путем революции (Пилсудский) или международной поддержки (Домбский), опираясь на Россию (Домбский) или страны Антанты (Пилсудский). В то же время Россия витала в иллюзиях панславизма не желая замечать национального роста «окраин», постоянно питавшегося ее экономическими и военными неудачами. Жесткий абсолютизм постоянно терял позиции внутри страны и неизменно сужал социальную базу сторонников. В условиях грянувшей Первой мировой войны царизм вновь не сориентировался в национальном вопросе и не

1 Октябрь 1917 и судъбы политической оппозиции: b 3-х частях / редкол.: Г.Г. Каспаров, Н. С. Сташкевич; под общ. ред. Э. М. Энтина. - Гомель: Белорусское агентство научно-технической и деловой информации, 1993. - Ч. 2. C. 74 . 
успел переманить региональные элиты на свою сторону. Россия еще только рассматривала вопрос о возможном предоставлении автономии Польше и Финляндии, категорически отрицая такой вариант для представителей других угнетенных наций, в то время как Германия заявила 5 ноября 1916 г. о создании Польского самостоятельного государства на землях Царства Польского. И тут же все политические элиты наций, которые ранее готовы были идти на соглашение с Петербургом об автономии, обратили свои взоры к странам Центральной Европы и устремили все усилия против «насильственной русификаторской политики».

Национальный фактор сыграл исключительно важную роль в событиях 1917 г., определяя прогрессивный и революционный характер происходившего. В то же время глубина проникновения и понимания национальной государственной идеи в различных регионах была неодинаковой. В Беларуси представители общественно-политических организаций и партий от имени народа требовали национальнотерриториальной автономии в рамках такой ограниченной административной единицы как край (А. Цвикевич и др. вообее выступали за национально-культурную автономию), значительно сужая национальный фактор ради расширения социальной базы своей работы.

На территории Украины этот процесс пошел иным путем. Решение всех социальных проблем лидеры партий и общественных организаций видели в актуализации национального фактора. Председатель Украинской Центральной рады М. С. Грушевский требовал широкой национальнотерриториальной автономии и предоставления права национальной элите самостоятельно искать пути и варианты решения проблем, возникающих в Украине с одной стороны, а с другой - иметь право самостоятельно распоряжаться национальными богатствами, налогами и доходами от международных соглашений. Но перераспределение налогов приводит к тому, что Украина обратно получает только часть, а остальными благами пользуются российские чиновники. Понимание этого момента у представителей белорусских организаций сложилось слишком поздно. Если в июне 1917 г. украинские национально-демократические организации посредством Центральной рады уже смогли добиться ряда уступок от Временного правительства и получили международную огласку с требованием создания Украинского государства, то в это же время на территории Беларуси, во многом по аналогии с украинским сценарием, изза бездействия Белорусского комитета, была проведена его реорганизация в Центральную раду белорусских организаций (в июле 1917 г.), которая также активности не проявила. 
М. Грушевский в марте 1917 г. на украинском вече в своем выступлении на Софийской площади в Киеве указывал на то, что 270 лет прошло с того времени как Б. Хмельницкий поднял народ на борьбу за свою государственность. Но «лукавое московское правительство» придушило свободный украинский народ, в связи с чем, призывал вместе со всеми народами Восточной Европы бороться за государственное право Украины. В статье «Велика хвиля» М. Грушевский писал о том, что уже через четыре года в 1658 г. - украинский народ в манифесте заявил о разрыве связей с Москвой, «но царское правительство, взяв под свою руку украинский народ, - уже не хотело отпускать его от себя». В это же время С. Петлюра пытался всколыхнуть огромные массы солдат-украинцев, которые находились на Западном фронте. На собрании в Минске он, указывая на нарушение Россией договора Б. Хмельницкого, призывал к организации украинских сил на фронте, ибо «только организованный народ сможет использовать ту свободу, которую теперь получил, и закрепить свои политические и национальные права, которые наиболее полно смогут выявиться только при демократически-республиканском и федеративном устройстве России, с автономной Украиной»².

Таким образом, национальные устремления окраинных народов всколыхнули Российскую империю, но не заставили Временное правительство пойти на кардинальные изменения. Более того, Московское и Петроградское совещания 1917 г. засвидетельствовали враждебное отношение русской общественности к идее национально-территориальной автономии.

Кардинально иной подход продемонстрировало советское руководство. Направленный в 1919 г. в Минск А.А. Иоффе констатировал, что «обстоятельства не благоприятствовали нам (большевикам - А. К.) в начале октября (1917г.), когда националистическое движение в среде мелких национальностей означало победу мелкобуржуазных элементов». Это заставило советское руководство изменить тактику при решении национального вопроса. Приняв в ноябре 1917 г. Декларацию о самоопределении народов вплоть до отделения, большевики попытались предопределить трансформацию национальной борьбы в классовую. Но, по мнению А.А. Иоффе, «период «большевизации» России закончился

\footnotetext{
2 Вестник комитета Западного фронта. - 1917. - № 294(450). - С. 2.
} 
Брестом. Настала реакция, от нас стали отпадать целые области»³. И снова же по примеру Украинской народной республики, а позже и Литовской тарибы представители белорусских организаций, в лице Исполкома Всебелорусского съезда, выступили за идею провозглашения Белорусской народной республики. Однако эта идея была настолько далека от ожиданий, жизненных интересов и стремлений народа, что представители белорусской интеллигенции, так и не смогли стать реальными политиками, а значит и идея реализации проекта независимого Белорусского государства, повисла в воздухе. Тем не менее, она получила международный резонанс, что заставило лидеров РСФСР также обратить внимание на этот вопрос.

Руководство Советской России, четко представляя себе ситуацию, с которой придется столкнуться на территории Беларуси и Украины, использовало тактику германских оккупационных властей, несколько её модернизировав. Как немецкие оккупационные власти на территории Украины осуществляли свою продовольственную программу под прикрытием оказания помощи независимым государствам, так и советское руководство продекларировало создание Социалистической Советской Республики Украины и пошло дальше, признав независимость и Беларуси. Однако относительно содержания правительств, созданных на территории Беларуси и Украины, большевистское лобби Москвы озаботились об их социалистической ориентации и стремлении к союзу с Советской Россией. Манифест 1 января 1919 г., провозгласивший создание Социалистической Советской Республики Белоруссии, представлял все национальное только в негативном свете: Беларусь измучена «польским вельможным панством», захвачена «российским кровавым самодержавием», пережившая «тяжелое ярмо немецкой оккупации», «украинских захватчиков», «петлюровских самостийников», которые вместе с «поганой Радой» (БНР - А. К.) объявлялись «злейшими врагами вашими (имелись ввиду белорусские рабочие и бедные крестьяне - А. К.) и трудящихся всего мира, заслуживающими беспощадной революционной кары» ${ }^{4}$.

Попытка подавить национальный фактор проявилось в следующих тактических приемах: введение нейтральных лиц для осуществления

3 Знешняя палітыка Беларусі: Зборнік дакументау і матэтыялау / пад рэд. I. І. Антановіч, У. М. Міхнюк, В. К. Ракашэвіч. - Мінск: БелНДІДАС, 1997. - Т. 1 (1917-1922 гг.). - С. 95.

4 Знешняя палітыка Беларусі: Зборнік дакументау i матэтыялау / пад рэд. I. І. Антановіч, У. М. Міхнюк, В. К. Ракашэвіч. - Мінск: БелНДІДАС, 1997. - Т. 1 (1917-1922 гг.). - С. 85. 
общеполитического руководства республиками, провозглашение стремления к объединению с РСФСР. Относительно Беларуси просматривались и отличительные меры: произведено выделение губерний и объединение с Литвой. В целях минимизации националистических настроений для общеполитического руководства в Харьков посылался Х.Г. Раковский, а в Минск - А.А. Иоффе. 9 января 1919 г. Временное рабочекрестьянское правительство ССРУ было преобразовано в Совет Народных Комиссаров во главе с Х.Г. Раковским, который прибыл в Харьков, чтобы сгладить конфликт, возникший между Г.Л.Пятаковым и членами правительства. В Минск для общеполитического руководства направили А. А. Иоффе, который до этого работал в Харькове в качестве члена ЦК РКП (б) по организации вооруженной борьбы с А. И. Деникиным и С. В. Петлюрой. Мотивируя введение нейтрального лица (как в Харькове Х. Г. Раковского), руководители Советской России указывали, что это «смягчит группы белорусов и облискомзаповцев» ${ }^{5}$. На заседании ЦБ КП (б) Б Я. М. Свердлов заявил, что создание единой ССРЛиБ - это требование международной политики, при реализации которого возникает противостояние центра с местными организациями. О напряженности взаимоотношений А. А. Иоффе и лидеров ССРБ свидетельствует его письмо к Я. М. Свердлову, в котором он сообщал, что «белорусы (группа Д. Ф. Жилуновича) - националисты, а поэтому насаждают сепаратизм, а наши (группа А. Ф. Мясникова), хотя и не националисты, но сепаратисты еще худшей марки» ${ }^{6}$ Предлагал распустить обе группы.

А.Ф. Мясников в 1921 г. указывал на тот факт, что появление оппозиции в рядах коммунистической партии связано с так называемой украинской оппозицией. «Навязывание местам новых, сверху назначенных партийных комитетов, целых властей (даже правительств!) и отдельных работников. Посылка на места задиристых неприступных уполномоченных. Давление на периферии в противовес «областничеству» и «самостийности». В этом надо искать значительную часть оппозиционности в партии. Перемещение («ссылка») отдельных групп и товарищей неподходящих для данной обстановки или не оправдавших себя на работе. Личный режим и личная диктатура, проявленная со

5 Первое января 1919 года: Временное рабоче-крестьянское правительство Белоруссии: документы и материалы. / сост. В.Д. Селеменев (рук.) [и др.]; науч. ред. М. Ф. Шумейко. - Минск: Лимариус, 2005. - 304 с., с. 67.

${ }^{6}$ Гісторыя Беларусі: падручнік: у 2 ч. Ч. 2. Люты 1917 г. - 2004 г. / Я. К. Новік [і інш.]; пад рэд. Я. К. Новіка, Г. С. Марцуля. - 2-е выд. - Мінск: Выш. шк., 2006, с. 70. 
стороны отдельных руководящих товарищей» .

Руководству советских республик была поставлена задача, инициировать вопрос об объединении с Советской Россией. Эти положения были общими для Беларуси и Украины. Особенность геополитического положения и истории национального движения привели к следующим тактическим шагам: во-первых, перед руководством Беларуси ставится задача выступить центром распространения социалистических идей в странах Прибалтики; во-вторых, в то же время в условиях возникающей польской угрозы принимается решение произвести выделение из состава Беларуси «Витебской, Смоленской, Минской, а в будущем и Могилевской губерний». Пленум ЦКРКП (б) 16 января 1919 г. поставил задачу, планируемому на 2 февраля съезду Советов Беларуси, «взять на себя инициативу о начале таких же переговоров с Советской Российской Республикой о соединении с недавно образованными Советскими Республиками (Латвией, Эстляндией и Литвой и т.д.). С таковым предложением съезд должен обратиться к указанным республикам»8.

В правилах Наркомпрода РСФСР о выезде в прифронтовую зону указывалось, что «лица едущие в пределы местностей Российской Советской Федерации, как-то в Латвию, Эстляндию, Литву, Белоруссию и Украину предоставляют и разрешение соответствующей Комиссии по национальным делам» 9 . Но, как известно, уже 16 января принимается решение о значительном территориальном уменьшении ССРБ. Рассмотрение деятельности Наркомпрода позволяет установить, что в ответ на попытку коллегии Минского райпродкома от 17 января 1919 г. подчинить губпродкомы Смоленской, Могилевской и Витебской губерний Компроду Беларуси в отношении контроля, руководства и организации комиссия продовольствия РСФСР 3 февраля 1919 г. направила в комиссию продовольствия ССРБ выписку из протокола заседания коллегии при Наркомпроде РСФСР от 13 января 1919 г. о ликвидации Снабзапа (комитета по снабжению западного фронта). В записке говорилось о том, что

7 Рукопись книги А.Мясникова «3а партию», изданная в 1921 г. и фотографии А.Ф. Мясникова // НАРБ. - Фонд 1440. - Оп. 3. - Д. 100. - Л. 53.

8 знешняя палітыка Беларусі... - С. 92.

9 Постановления и приказы Наркомпрода РСФСР и Литбел о продовольственном пайке для учащихся единых трудовых школ, порядке выдачи продуктов и ценах на сено и солому, правила выдачи пропусков на право выезда в прифронтовую и пограничные полосы, план распределения товаров Минским губпродкомом и справки о ценах на таксированные и нетаксированные продукты // Фонд 806. Оп. 1. - Д. 82. - Л. 5 
«губпродкомы Смоленской, Могилевской и Витебской губерний следует считать в настоящее время совершенно не зависящими от Компрода Белоруссии и что означенные губпродкомы будут включены в сметы Народного комиссара по продовольствию РСФСР» 10.

По мнению Наркома иностранных дел ССРБ создание Литбел завершилось 22 февраля 1919 г., после появления соответствующих резолюций, вслед за декларацией I Всебелорусского съезда Советов (2 февраля), одобряющих объединение Литвы и Беларуси, Виленского совета депутатов (20 февраля) и съезда Советов Литвы (22 февраля). Однако процесс организации государственных учреждений власти завершался в ССРЛиБ немного позже.

24 февраля 1919 г. М. И. Калманович выступил на заседании коллегии Компрода ССРБ с докладом «о необходимости переезда Компрода в Вильно в виду слияния Белоруссии и Литвы и объединения центральных учреждений»11. 25 февраля был создан Минский губревком, в связи с чем, был сохранен особый статус Минска, необходимый для сохранения непосредственных торговых отношений с Украиной. На заседании коллегии Наркомпрода РСФСР 25 февраля 1919 г. сообщалось, что «через неделю произойдет слияние Компродов Белоруссии и Литвы. Местонахождение объединенного Компрода - Вильно»12. Постановили одобрить переезд М. И. Калмановича и наметить работников, которых необходимо перевести в Вильно. В приказе № 4, изданном Компродом ССРБ в Минске 2 марта 1919 г. указывалось, что «вследствие слияния Белорусской и Литовской республик Компрод Белоруссии с 3 марта переводится в Вильно»13.

Слияние Беларуси с Литвой произошло в пределах 4-х губерний: Минской, Гродненской, Виленской, Ковенской и части Сувалковской с населением более 4 млн. человек. Органами власти выступали

10 Циркуляры, инструкции и протоколы заседаний коллегии Наркомпрода РСФСР, типовой проект учреждения в составе Комиссариата продовольствия и др. / / Фонд 806. - Оп. 1. - Д. 10. - Л. 1.

11 Приказы по Народному комиссариату продовольствия ССРЛиБ, комитету, протоколы заседаний коллегии продовольственного комитета // Фонд 806. - Оп. 3. - Д. 4. - Л. 79.

12 Циркуляры, инструкции и протоколы заседаний коллегии Наркомпрода РСФСР, типовой проект учреждения в составе Комиссариата продовольствия и др. // Фонд 806. - Оп. 1. - Д. 10. - Л. 24.

13 Приказы по Народному комиссариату продовольствия ССРЛиБ, комитету, протоколы заседаний коллегии продовольственного комитета // Фонд 806. - Оп. 3. - Д. 4. - Л. 56. 
Центральный исполнительный комитет ССРЛиБ и его президиум во главе с К. Циховским, а также правительство республики - Совет Народных Комиссаров во главе с $\quad$ В. С. Мицкявичусом-Капсукасом. На объединительном съезде (4-6 марта 1919 г.) был избран ЦК КП (б) ЛиБ.

Таким образом, государственная идея в Беларуси прошла сложный и долгий путь становления. Период самодержавия наложил свой отпечаток на мировоззрение национальных лидеров, которые до начала XX века рассматривали развитие своих народов только в контексте общерусской истории. От этой концепции украинские лидеры начали отходить в ходе революционных событий 1917 г., а белорусские идеологи пришли к этому только после подписания Брестского мира. Судьба белорусского народа, в итоге стала прерогативой руководства Советской России. Тактические цели большевиков в отношении провозглашения независимых советских республик Беларуси и Украины определялись стремлением противостоять нарастающему национальному движению и усиливающемуся влиянию западных соседей на события внутри страны. Цепь небольших национальных буферных республик должна была погасить пламя гражданской войны внутри страны и отбить желание в проведении иностранных интервенций.

PhD Alexander Kuksa (Minsk, Belarus).

\section{STATE IDEA IN BELARUS: PROBLEMS OF FORMATION AT THE BEGINNING OF THE TWENTIETH CENTURY}

The article is devoted to the formation of a statist consciousness of the political elite of Belarus during 1900-1919. The author pays attention to the interaction of the Belarusian and Ukrainian models of statist movements, analyzes the attitude to the Belarusian "separatism" from the tsarist autocracy and the Bolsheviks.

Keywords: Belarus, Ukraine, Lithuania, Moscow, Bolsheviks, Autocracy, Separatism, Litbel.

Александр Кукса (Минск, Беларусь).

ГОСУДАРСТВЕННАЯ ИДЕЯ В БЕЛАРУСИ: ПРОБЛЕМЫ СТАНОВЛЕНИЯ В НАЧАЛЕ ХХ ВЕКА

Статья посвящена формированию государственнического сознания политической элите Белоруссии в течении 1900-1919 гг. Автор уделяет внимание взаимодействию белорусской и украинской моделей государственнических движений, анализирует отношение к белорусскому «сепаратизму» со стороны царского самодержавия и большевиков.

Ключевые слова: Беларусь, Украина, Литва, Москва, большевики, самодержавие, сепаратизм, Литбел.

Олександр Кукса (Мінськ, Білорусь). 
ДЕРЖАВНА ІДЕЯ В БІЛОРУСІ: ПРОБЛЕМИ ЕВОЛЮЦІЇ НА ПОЧАТКУ ХХ СТОЛІТТЯ

Стаття присвячена формуванню державницької свідомості політичної еліти Білорусі протягом 1900-1919 рр. Автор приділяє увагу взаємодії білоруської та української моделей державницьких рухів, аналізує ставлення до білоруського «сепаратизму» з боку царського самодержавства і більшовиків.

Ключові слова: Білорусь, Україна, Литва, Москва, більшовики, самодержавство, сепаратизм, Літбел.

* Кукса Александр Николаевич - кандидат исторических наук, доцент кафедры «Политология, социология и социальные учения» Белорусского национального технического университета. E-mail: akuksa@bntu.by. 